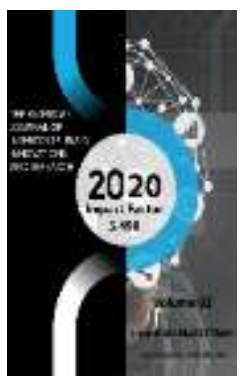

Journal Website: http://usajournalshub.c om/index,php/tajiir

Copyright: Original content from this work may be used under the terms of the creative commons attributes 4.0 licence.

\section{Geoturism And Geoparks - A Way Of Developing The Economy Without Non-Traditional And Mineral Raw Materials}

\section{P.S. Sultonov}

Acting Professor, Doctor Of Geological And Mineralogical Sciences, National University Of Uzbekistan Named After Mirzo Ulugbek, Uzbekistan

\author{
M.U. Atakulova
}

Methodist Of The Internal Control And Monitoring Department Of The Almalyk Branch Of Tashkent State Technical University Named After Islam Karimov, Uzbekistan

\title{
ABSTRACT
}

Geotourism and Geoparks - a way to develop the economy without unconventional and mineral resources of subsoil use. From the point of view of the tourism business in the world, Geoparks are considered a key component of the national, historical and cultural heritage. According to many studies, this approach is one of the most effective forms of marketing.

\section{KEYWORDS}

Geopark, siltstone, sandstone, dolomite, marl, gypsum, anhydrite.

\section{INTRODUCTION}

There is every reason for the development of geotourism in the territory of the Republic of Uzbekistan. Some regions or objects in our country are important from an economic, scientific, cultural and environmental point of view. It is known that geotourism as a type of ecotourism is a relatively new and one of the fastest growing areas of world tourism. From a geological and economic point of view, geotourism is interpreted as a specific method of subsoil use. In this case, the land and its resources are used only for informational, 
informational and aesthetic purposes, without touching them. In this regard, geoparks are the main object of geotourism.

\section{THE MAIN FINDINGS AND RESULTS}

A geopark is a kind of natural park, the systemforming elements of which are various geological formations observed in nature and are of great importance from a scientific, aesthetic and ecological point of view. The organization of geotourism and geoparks is based on economic, scientific, educational, aesthetic and environmental aspects of such processes as diversification of the country's raw material base, saving resources, ensuring environmental safety, and producing environmentally friendly products.

The following main technical and economic indicators are important for the organization of geoparks:

1. Components of the system of geoparks consist of one or more natural geological formations;

2. The possibility of including in the composition of geoparks natural or artificially created objects that have nothing to do with the geopark ethnographic, historical, architectural and other objects;

3. Geoparks are naturally occurring and are considered to be tourist attractions with the status of a national museum;

4. Infrastructure in the territory of geoparks should be well developed and have sufficient base for service.

5. The economic efficiency of the geopark depends on the following factors:

- The scientific, cultural and aesthetic significance of the object meets the requirements of UNESCO;
- Involvement of local population in the activities of the facility and their interest in this work;

- High level of business plan;

- level of development of infrastructure and service bases;

- advertisements.

Based on the above requirements for Geoparks and the results of our many years of research, it can be recognized that there are many places in the country where such tourist attractions can be organized. To do this, you only need to fully understand why the proposed Geoparks are valuable and can attract the attention of tourists.

Typically, geologists begin their study of sedimentary deposits from any geologic period with the natural discoveries they have made on the surface today. At the same time, the rocks related to each natural hole are described in detail layer by layer, the conditions of the deposits are determined, their thickness is measured and samples are taken from them for studying the material composition in various laboratories. The lithological sections of the more clearly defined opening, expressed in conditional symbols, are constructed and compared with the adjacent opening section adjacent to it, and so on. The greater the number of such cuts, the more accurate the data obtained by comparing them. In particular, it helps to obtain detailed information about the relative age (stratigraphy) of each geological period, the structural changes in the rocks, the conditions of formation and mineral deposits. Usually things like this don't go very easily. The reason for this, as mentioned above, is that the complete preservation of natural openings is primarily hampered by tectonic movements. In other words, a whole deposit, which is scattered under the influence of tectonic 
movements, specific to a certain geological period, is restored to its previous state by studying their specific properties. The importance of whole, fully preserved geological sections, which were not affected by tectonic movements or had very little effect when they were affected, is of great importance in carrying out such reconstructions. Because they determine the stratigraphic age of rocks consisting of other semi-cross-sections and the associated mineral horizons.

In the long geological past of our planet (between 23-65 million years ago), a geological period called the "Paleogene period" prevailed. Its deposits are the product of the Tethys Sea, which occupies most of the globe and is widespread throughout Central Asia, including the territory of our country $[1,8]$. Genesis (conditions of formation) of Paleogene deposits formed by the Tethys Sea, lithology - type of rock [4], stratigraphy - age stratification of strata [5], paleontology - fauna and flora of rocks [2,3], paleogeography geological past geography [6] and, in connection with the deposits of this period, mineral deposits such as oil and gas have been studied and explored in detail by many foreign and domestic geologists [9]. Naturally, this research will continue in the future. The Paleogene deposits we are considering are also widespread in the territory of our country. They are well studied from a geological point of view and have achieved certain successes. Scientists who have studied the geological age of the deposits of this period have developed a scale of its international and local stratification (table). The purpose of developing a stratigraphic scale of each geological period is to determine the age of its fine stratigraphic units (tier, formation, or stratum). This work is based on the study of the material composition of the rocks peculiar to these units, as well as the fossil organic residues in them. Such tasks are studied by paleontology. Take the "Rishtan" tier on the stratigraphic scale as an example. This stratum, which corresponds to the Barton (?) Stratum on the International Stratigraphic Scale, is part of the Paleogene deposits exposed around the city of Rishtan in the Fergana region. fossils differ in the type of organic residue. Similar ideas can be emphasized for other tiers as well.

Naturally, for almost 40 million years, the water level of the Paleogene Sea has not remained the same. Due to global tectonic movements, its surface has repeatedly risen (transgressed) and fallen (regressed), the climatic conditions of the regions (from arid to humid climate) and the chemical composition of seawater have changed. The result is sedimentary rocks of various compositions - clay, siltstone, sandstone, dolomite, marl, gypsum, anhydrite with a thickness of several tens of meters to several hundred meters. 
Stratigraphic stratification of Paleogene deposits

\begin{tabular}{|c|c|c|c|c|c|c|}
\hline Erotema & System & Section & Subsection & $\begin{array}{l}\text { Tier } \\
\text { (international) }\end{array}$ & Tier (local) & $\begin{array}{c}\text { Age } \\
\text { (Million } \\
\text { years) }\end{array}$ \\
\hline \multirow{11}{*}{ Cenozoic } & Neogen & Miocene & Lower & Aquitaine & Massaget & 20,43 \\
\hline & \multirow{9}{*}{ Paleogene } & \multirow[t]{2}{*}{ Oligocene } & High & Xatt & Sumsar & 23,3 \\
\hline & & & Lower & Ryupel & Khanabad & 28,4 \\
\hline & & \multirow[t]{4}{*}{ Eotsen } & High & Priabon & Isfara & 33,9 \\
\hline & & & \multirow[t]{2}{*}{ Medium } & Barton & Rishton & 37,2 \\
\hline & & & & Lyutet & Turkiston & 40,4 \\
\hline & & & Lower & Ipr & Oloy & 48,6 \\
\hline & & \multirow{3}{*}{ Paleocene } & High & Tanet & \multirow{2}{*}{ Suzoq } & 55,8 \\
\hline & & & & Zeland & & 58,7 \\
\hline & & & Lower & Dat & Bukhara & 61,7 \\
\hline & Cretaceous & \multicolumn{2}{|l|}{ High } & Maastricht & Senon & 65,5 \\
\hline
\end{tabular}

The deposits of this period mainly filled the concave relief surfaces typical of that period. Therefore, as their thickness thickened in the deeper part of the relief, it shrunk as they approached the shore, encircling the heights or mountains surrounding the seawater. Naturally, his beds were initially horizontal in appearance. We can also learn this from the well-preserved deposits of the sea to this day, and from the fossilized shells of the various district marine animals found in them.

The post-Paleogene geological period is the end of the Neogene, when another deformation (Alpine deformation) took place all over the globe and caused horizontal deformation and even overturning of the rock layers lying horizontally, typical of the Paleogene period. The strong mountain rises that took place during this period undermined the integrity of the deposits we are considering. To date, we can observe Paleogene deposits on the slopes of large mountain ranges, and their continuation on the basis of core materials obtained from deep boreholes drilled in the central parts of the valleys, and sometimes see fragments of Paleogene deposits that have been washed away in the high peaks. In short, it is impossible to meet, observe and study the naturally discovered reference deposits, where the 
stratigraphic units of the Paleogene period are fully preserved[7].

In this regard, the Paleogene deposits, located on the southern slopes of the Qurama Mountains, in the south-east of Gova village, Chust district, Namangan region, have their own cross-section, stratigraphic units are fully preserved, are clearly bounded by Cretaceous and Neogene deposits below. and is located in a very convenient location for organizing ecotourism and is close to the residential area (picture).

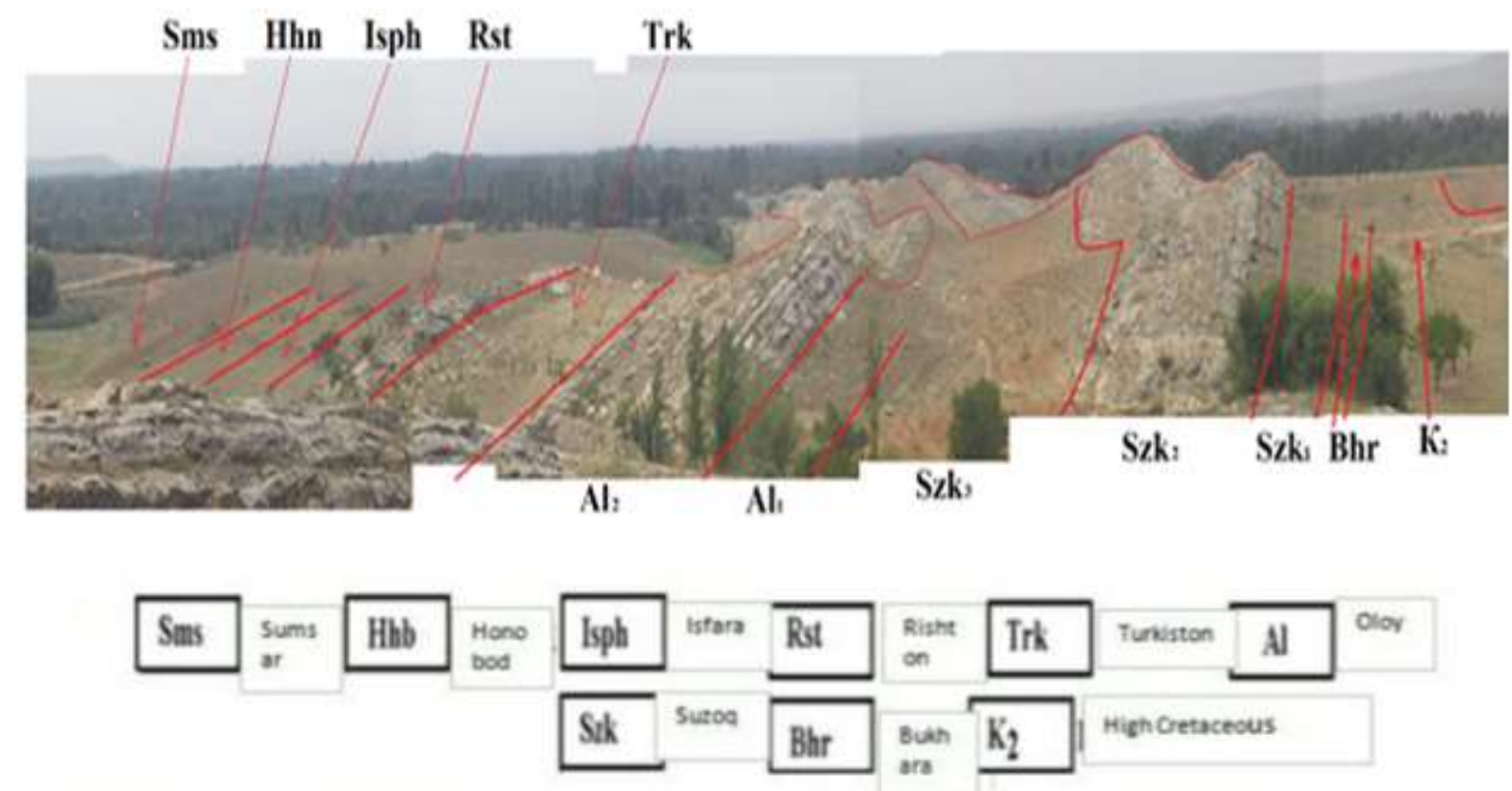

A cross section of Paleogene deposits discovered in the southeastern part of the village of

\section{Gova}

\section{CONCLUSION}

The proposed section of the Paleogene as an object of ecotourism, with its complete preservation, indicates the importance of studying and stratigraphic comparison of the deposits of this period not only in Uzbekistan, but also in Central Asia as a whole.

Studies conducted by Chinese scientists to compare the reference section of these Paleogene deposits in the northern part of the Fergana Valley with the cross section of
Paleogene deposits in the Tarim Valley of China confirm that the site is one of the rare objects of international importance.

It is advisable to take measures to define the boundaries of the protection of the territory and pass it on to the next generation, so that local residents do work on this site, such as opening additional land for agriculture, digging ditches for water, moving limestone layers as building material. 


\section{REFERENCES}

1. Atlas of lithological-paleogeographic, structural, palinspastic and geoecological maps of Central Eurasia . Almaty: Publisher: "NII Natural Resources YUGGEO”, 2002. -p. 66.

2. Bykova N.K. Materials for the paleoecology of foraminifera of the Suzak stage of the Paleogene of the Fergana Valley. / Tr. VNIGRI. L.-M: 1973. 73. - pp. 210-225.

3. Sultonov P.S; Tsatsir E.F. New data on paleontological remains and stratigraphy of the Paleocene of South Fergana // Dokl. Academy of Sciences of the Uzbek SSR. - 1990. - No. 11. -pp. 47-49.

4. Sultonov P.S. Facies-paleogeographic conditions of the formation of the Paleogene of South Fergana and associated minerals // Geology and Mineral Resources. 2015. No. 3. - pp. 38-45. 